\title{
新しい回折物理学の展開と放射光科学の推進
}

(財) 高輝度光科学研究センター 菊田惺志

\section{Seishi KIKUTA: Development of Diffraction Physics and Promotion of Synchrotron Radiation Science}

In the 1970's, the X-ray crystallographers have expected to use synchrotron radiation for further developing their researches. We have cooperated to construct the synchrotron radiation facilities, Photon Factory and SPring-8 from the user side. In this report I look back my activities in the user communities to realize the synchrotron radiation sources. Next, I describe some scientific achievements made using synchrotron radiation. They include the studies of $X$-ray dynamical diffraction, X-ray optics, X-ray surface diffraction, X-ray nuclear resonant scattering, and X-ray quantum optics.

\section{1. はじめに}

本稿は, 2005 年 12 月 6 日に日本結晶学会年会で行っ た西川賞受賞講演を骨子として，それに若干の肉付けを したものである. 私の研究生活のかなりの部分は放射光 (Synchrotron Radiation, SR) にかかわっていた. 特に Photon Factory (茨城県つくば市) と SPring-8 (兵庫県西播 磨）の放射光光源の実現のために利用者の立場から尽力し たので, まずその経緯について述べる. 結晶学会ではX 線, 電子線, 中性子線などによるビーム実験が主要な部分を占 め, 光源の高性能化が研究の進展に不可欠であるので, 振 り返ってみて私が長期間にわたりそれに相当の時間を費 やしたのは，それなりに役立ったことと思う．次に放射光 科学の発展をめざして行ってきた研究を中心に述べる. 初 期に行った動力学的回折現象の観測などに触れたあと,そ れに関連してX線ビームの高品質化を困ったX 線光学の 研究について述べる. 続いて, 放射光利用研究として結晶 表面の構造解析法を開拓し, X 線核共鳴散乱法の基礎固め をするとともに, X 線量子光学のさきがけ的研究などを行 ったので, それらについて紹介する. 最後に放射光科学全 体の発展状況と将来展望に言及する。

なお, 放射光施設の実現とその利用のような大きなプロ ジェクトは, いろいろな機関の多くの関係者がそれぞれの 役割を果たして達成されるものであるから, 回顧すればそ れぞれの道筋があるはずである.ここでは私が辿った道筋 であることをお断りしておきたい.

\section{2. 放射光光源とのかかわり}

X 線源の輝度が年代的に増加していく様子を表したの が図 1 である.輝度の増加はもっぱら放射光によってお り, 最初は偏向電磁石光源が利用された. さらに挿入光源 日本結晶学会誌 第 48 巻 第 3 号 (2006)

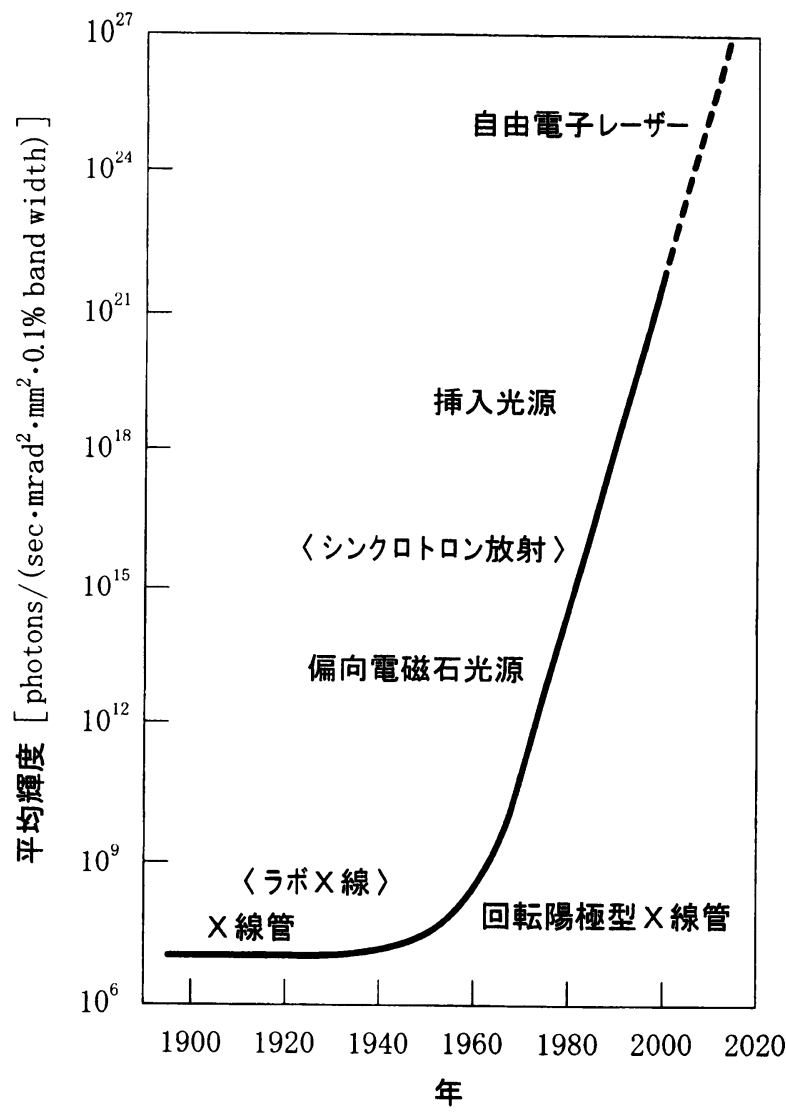

図 $1 \mathrm{X}$ 線源輝度の年代的な向上. (Yearly increase of the brilliance of $\mathrm{X}$-ray sources.)

の導入により高輝度化が図られている. 近い将来にはX 線自由電子レーザーが利用可能になる見通しである.これ までの放射光光源の高輝度化は光源用円形加速器の発展 によって段階的に分類することができる. 第 1 世代は高工 ネルギー物理用の既存のリングで, 放射光用に寄生的に使 用された。第 2 世代は光源専用の蓄積リングで, 偏向電磁 
石光源が主体である.X線用のリングについてみれば, Photon Factory は第 2 世代であるが, その後のリングの高 度化により性能的に第 3 世代に近づいている. 第 3 世代 は低エミッタンスの大型蓄積リングで, アンジュレータ 一光源が主体である.これにはヨーロッパのESRF, 米国 の APS とともにSPring-8が入る.さらに最近，スイスの SLSのようにミニギャップ・アンジュレーターを利用す る低エミッタンスの中型蓄積リングが第 3 世代に参入し つつある.

\section{$2.1 P F$ の実現に向けて}

電機関係の会社から戻り1962 年から東京大学教養学部 物理教室の高良和武先生の研究室で, シリコンのような 完全に近い単結晶におけるX線の動力学的回折現象の研 究を始めた。二結晶あるいは三結晶配置の回折計を用い た実験では, $X$ 線強度の弱さが研究遂行上のネックであっ た. 当時, $X$ 線結晶学の分野は手法の面では, その限られ た X 線強度の範囲ではすでにかなり成熟期に達している ように思われた。このような状況の中でX線利用の研究 を将来, 飛躍的に発展させるには超強力な $\mathrm{X}$ 線源の実現 が不可欠であると痛感された. 高良研究室は 1964 年に工 学部物理工学科に移り, X 線光学の研究が進められた. 当 時, 原子核研究所の電子シンクロトロン $(1.3 \mathrm{GeV})$ から得 られる放射光を寄生的に利用し, 世界に先駆けて極紫外 線分光の研究が進められていた. それに刺激されて, もっ と電子エネルギーの高い円形加速器からの放射光を利用
することにより強力な $\mathrm{X}$ 線源ができるのではないかと考 え, 適当な規模の加速器を想定して放射光強度を試算する と, X線管と比べて特性線のところでも管電流にして数 100A に相当するほど超強力であることが判明した. ${ }^{1)}$ 高良 先生もその数値に驚嘆された. 1971 年の物理学会におい て「超強力 $\mathrm{X}$ 線束の発生とその応用」という主題のシンポ ジウムが開かれ, 線源についていろいろな可能性が議論さ れたが, そこで放射光の利用を提案したところ, 大方の賛 同が得られた。 これを契機に, 超強力な $\mathrm{X}$ 線源として放射 光用リングを建設しようという気運が高まっていった. 同 じ年に科研費 (総合研究)「超高出力 $X$ 線発生装置建設計 画」が高良先生を代表者として組織され, 回折結晶学の先 生方に富家和雄先生をはじめ加速器関係の方が加わりこ の議論が深められた.2) 私はその年に生産技術研究所に 移り 8 年間在籍した後, 工学部物理工学科に戻った. 生産 研で研究室を立ち上げ, その前から継続中であったラボ軟 $\mathrm{X}$ 線によるホログラフィの実験で像再生に成功した.さら に核研の電子シンクロトロンから得られる放射光を初め て利用し同様の実験を行い, 放射光の強度が格段に強いこ とを実感した. また真空工学の辻 泰先生のご指導のもと で真空内での結晶表面の X 線回折の研究も始めた.

放射光 X線の利用を提案したころは，まだ世界的に SRX 線に対する関心はほとんどなく, 専用リングが実現 すればSRX 線利用の一番手になるはずであった. しかし 1970 年代後半には米国で既存の高エネルギー物理用リン

(a)

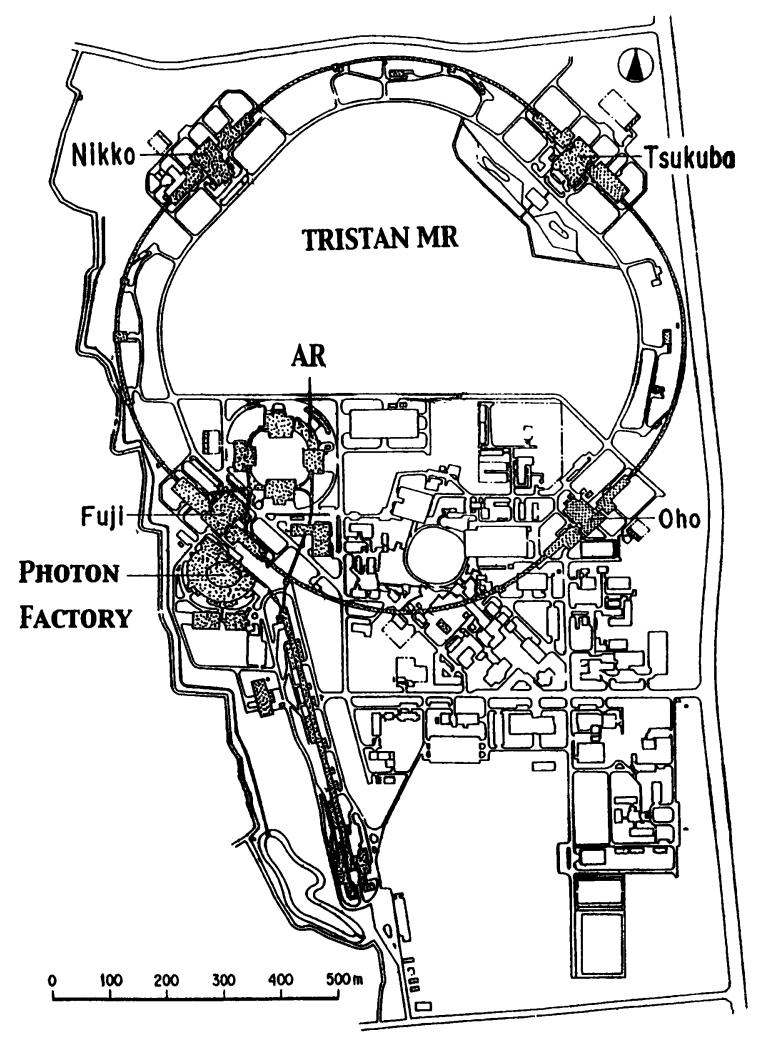

(b)

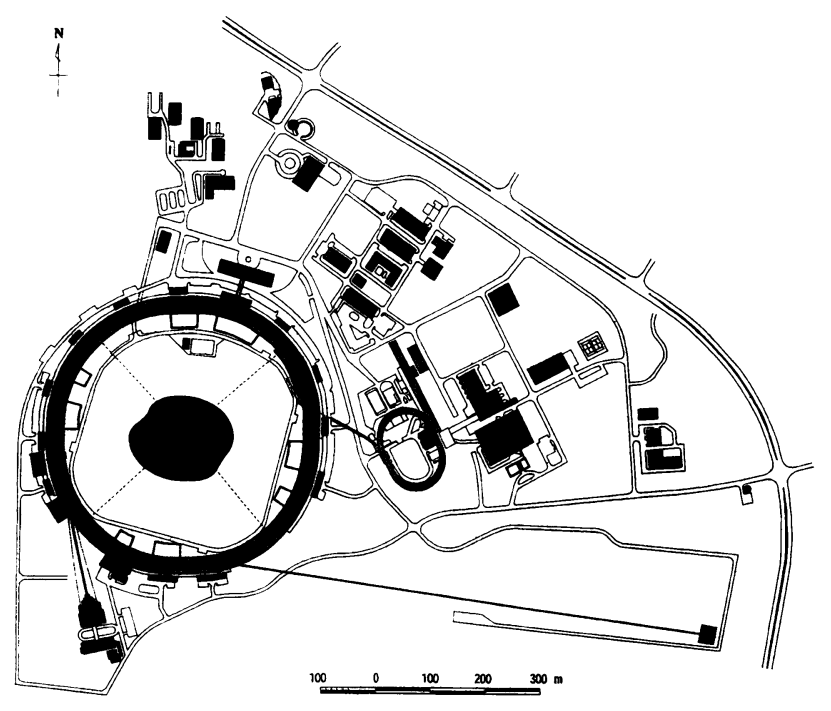

図2 (a) KEK と (b) SPring-8における放射光用加速器の配置図. (Maps of (a) KEK and (b) SPring-8.) 
グを寄生的に利用し始め, 西独, 仏もそれに続いた。この 外国の情勢に影響されてリング建設計画は具体化した。 1973 年にフォトンファクトリー世話人会が発足し, 1975 年にはフォトンファクトリー懇談会が設立された. 私もこ れらの活動に参加した. 1978 年に放射光実験施設の建設 が始められ，懇談会の作業グループが建設に協力した。 1982 年に PF (2.5 GeV) (図 2a) がX 線領域の専用リング として完成し, 世界で専用のX線リングをもつ先行グル ープの仲間入りをした. 初代の施設長を高良先生が務めら れ，そのあと佐々木泰三先生，千川純一先生と続き，PFの 基礎が築かれた. 私たちのグループは X 線光学, 表面構造 解析などで従来まったく不可能であった研究を行うこと ができた。

\section{$2.2 \mathrm{AR}, \mathrm{MR}$ の利用}

一方, 高エネ研では高エネルギー物理のトリスタン計画 が進んでいて, 周長 $3 \mathrm{~km}$ の巨大な主リング $\mathrm{MR}(30 \mathrm{GeV})$ と入射蓄積リング $\mathrm{AR}(6.5 \mathrm{GeV})$ が建設されていた(図2a). 1987 年にその AR が放射光用に寄生的に利用できるよう になった. 1990 年に真空封止型アンジュレーターが初め て AR に導入され，X 線領域での挿入光源利用の幕開けと なった.このアンジュレーターは ${ }^{57} \mathrm{Fe}$ 同位体の核共鳴エ ネルギー $14.4 \mathrm{keV} に$ 最適化されており, 私たちが長年準 備してきた核共鳴散乱の研究を科研費 (特別推進研究)の 支援を受けて, 一挙に進展させることができた。 なお PF は建設フェーズから本格的な利用フェーズに移り,フォト ンファクトリー懇談会の役割が変わってきたので, 1990 年に私が改組のまとめ役として施設者側と利用者側の交 流が活発になるように運営体制を変更した.ささらに改称し たPF懇談会の会長として懇談会の活性化に努めた. ちょ うどそのころ, 高エネルギー物理のトリスタン計画が終了 した後に, MRを放射光光源に転用しようという計画が もち上がり, 1991 年にMR 放射光計画推進室 (安藤正海室 長) が発足した.このリングからの放射光は第 3 世代リン グを超える特性をもつということで, その実現に大きな期 待が寄せられた。この計画の精緻化をするため1992年に PF 懇談会に超高輝度放射光計画検討委員会が設けられ， 私が委員長を務めた. その後 MRは高エネルギー物理の B ファクトリー計画に使われることになり, 不本意なが ら, 放射光への転用計画は消滅した.3) その代わり $\mathrm{B}$ ファ クトリーの工事が始まる前の 1995 年に短期間 (3 力月の 準備期間と 3 力月の実験期間) であるが, MRの放射光利 用の機会が作られた. 10 種類近い実験が実施され，われ われも X 線領域で光子相関の観測に初めて成功した.

\section{3 放射光科学コミュニティの形成}

放射光利用研究が発展し, 放射光科学と呼ばれる分野が 確立してきたので，1988年に日本放射光学会が設立され た. 当時日本全国で共同利用の放射光施設の建設計画が多 数提案されていたので, 放射光学会将来計画特別委員会で
総合的に検討された. 私は委員長を務め, アカデミックな 立場から SPring-8 と MR の大型施設計画はともに独自性 と相補性をもつので両者とも推進すべきものと提言し, 中 型施設計画については7 計画を評価して, 調査報告書をま とめた.4).5) 1993 年に放射光学会の会長を務めたとき, 全国 の放射光施設で個別に行われていたシンポジウムの研究 成果の発表会を学会の年会とまとめて, 一堂に会する合同 シンポジウムとするのを企画した. またアジア地域での放 射光研究交流をめざして第 1 回放射光アジアフォーラム を催した. いずれも好評で, 以後これらの行事は定着して いった。

\subsection{SPring-8の実現に向けて}

PFにおける放射光利用研究の発展によりもっと高輝度 の光源を望む声が大きくなり，挿入光源を主体とした第 3 世代リングの実現をめざす動きが出てきた. 1983 年に $6 \mathrm{GeV}$ 放射光施設を関西に建設しようという計画が関西 SOR 計画世話人会から提案された。これには三井利夫先 生がまとめ役となり, その後角戸正夫先生が会長として尽 力された. 私たちは1988年に建設地を特定しないサイ ト・インデペンデントの立場で次世代大型 X 線光源研究 会をオールジャパンの体制のもとに発足させた. そのとき の世話人の名簿を表 1 に示す.6) 塩谷亘弘, 下村 理両氏と はその後も長く, ともに活動した. 運営ワーキンググルー プでは施設完成後の共同利用体制について検討され，利用 研究関係では 10 の研究分野のサブグループが立ち上げら れた．同年に原研と理研の共同チームが結成され，上坪宏 道先生がリーダーを務められた. 研究会は科技庁, 共同于 一ムと頻繁に会合をもち, 目標達成に努力した. SPring-8 の光源の性能は研究会において検討されたが, その際まと められた各研究分野別サブグループが必要とした放射光 のエネルギーと光子数を図3に示す.これをもとにして蓄 積リングのエネルギーが当初案の $6 \mathrm{GeV}$ から $8 \mathrm{GeV} に$ 変更された. 1989 年に科学技術庁による SPring-8の建設 計画が軌道に乗り, 原研と理研が共同で建設をすることに なった.7) 1990 年にSPring-8完成後にその運営を行う財団 法人高輝度光科学研究センターが設立された. 1990 年か ら 4 年間, 研究会のサブグループが共同チーム利用系の研 究開発プログラムに参加し, 放射光利用のための機器開発 を行った. 1993 年には SPring-8 計画が準備フェーズから 建設フェーズに移行したので, 研究会を発展的に解散し, SPring-8 利用者懇談会を発足させた. 会員には広報誌「光 彩」が配布され，1996年頃には会員は千名を超えた. 研究 課題別サブグループは 35 チームに達し, 各サブグループ が研究目標を掲げてそれを実現するためのビームライン と実験ステーションの構想を練ったものが, SPring-8 Project - Scientific Programとしてまとめられた.8) 最初に 設置が予定されていた 10 本の共用ビームラインに対して サブグループから実験ステーション建設の提案が行われ, 
表 1 次世代大型 X 線光源研究会の 1988 年度世話人名簿. (List of representative members of the society for next generation large-scale X-ray source.)

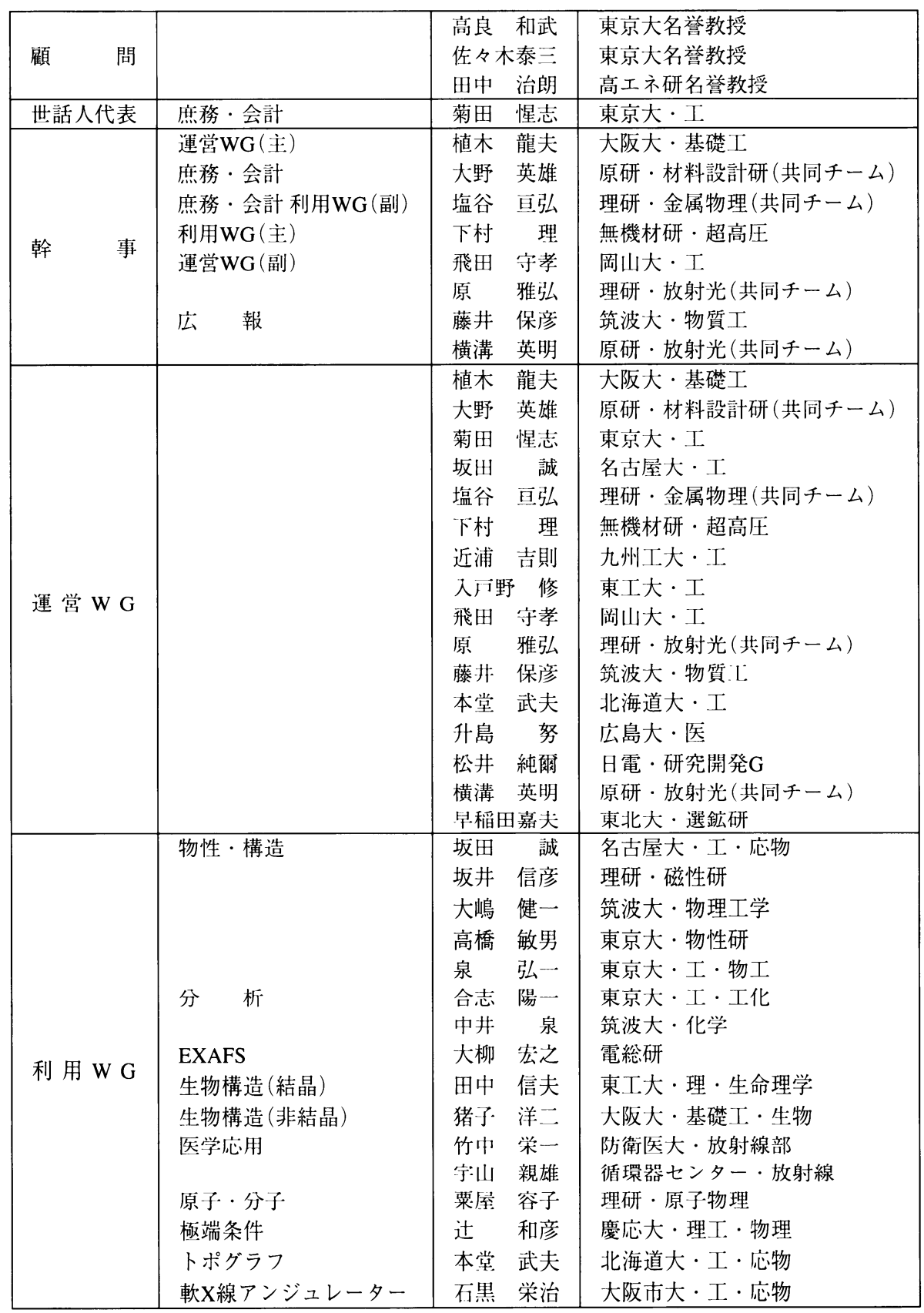

ビームライン検討委員会において 1993 年度に 4 本, 1994 年度に6本の研究分野が決定された.これらの実験ステー ションの建設には懇談会のサブグループの建設チームが 共同チームに協力した. 1997 年に SPring-8 (図2b) は研 究者の熱望に応えて, 科技庁, 原研 - 理研が主体となり, 兵庫県, 関西を中心とした財界・産業界の支援のもとで 共用開始を迎えることができた. $\operatorname{ESRF}(6 \mathrm{GeV}), \operatorname{APS}(7$ $\mathrm{GeV})$ とともに第 3 世代大型リングの 3 極を形成すること となった. 1998 年 3 月には財団と懇談会が共催で第 1 回 の SPring-8 シンポジウムを開いた.

共用開始後は原研・理研の委託を受けた財団が SPring-8 の共用業務, 運転・維持管理・高度化などを行うことに
なり放射光研究所の所長を上坪先生が務められた. 私は 1998 年に東京大学を定年退官し, 財団に移り, その副所 長を 6 年間務めた. 加速器は高度化により, 低エミッタン ス運転とともに, 最近トップアップ運転を実現している. また多種の仕様の挿入光源, ビームラインと実験ステーシ ヨンの利用により続々と顕著な研究成果が得られており, それらを目の当たりにできたのは私にとってとても幸せ であった. 現在稼動中のビームラインは 48 本で, まだ 14 本が残っているおり, 施設の有效利用のためにその建設が 待たれる。 


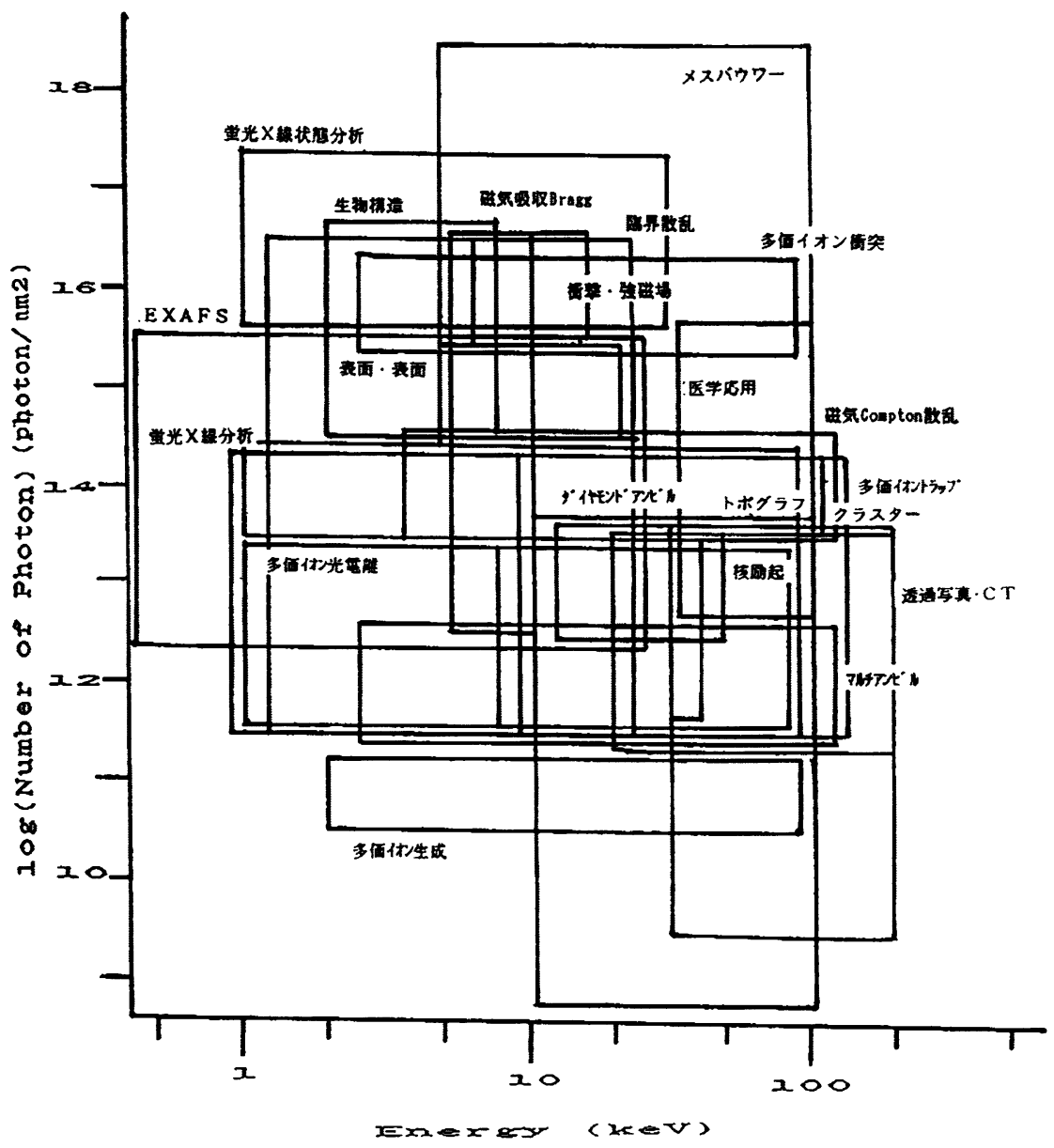

図 3 次世代大型 $X$ 線光源研究会において検討された, 各研究分野で必要とされる放射光のエネルギーと光子数. (Energy and photon number of synchrotron radiation necessary for various research fields surveyed by the society for next generation large-scale $\mathrm{X}$-ray source.)

\section{3. 放射光科学の発展をめざして}

\section{1 放射光利用以前の研究}

Photon Factory の放射光が利用できるようになる以前, 1977 年に結晶学会学術賞を受賞した. そのころまでの研 究は, 結晶学会誌に受賞にかかわって記載した報告に含 まれているので,9) 概略を述べる.

(1) X 線平面波の作製とその応用

1960 年代から動力学的回折の理論的, 実験的研究が盛 んであった．普通の実験条件では入射線は球面波である が，二結晶あるいは三結晶配置の回折計を用いて平面波 による動力学的回折現象の観測を行った. 小さい視斜角 の非対称反射を $(+,-)$ あるいは $(+,-,+)$ 平行配置で 繰り返すことによる擬似平面波の作製法を考案し(図4a), 発散角 0.1 秒〜 0.01 秒のビームを作製した. 10 ),11) それを用 いてシリコン結晶の固有な回折強度曲線の精密測定を行

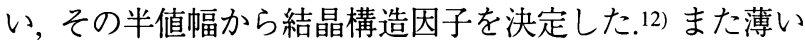
結晶からのロッキングカーブは振動的になることが古く から知られていたが，それをラウエケースで初めて観測 した.13) 平面波トポグラフィにも応用し，薄いくさび形結 日本結晶学会誌 第 48 巻 第 3 号 (2006)

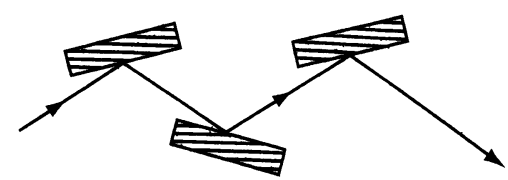

(a)

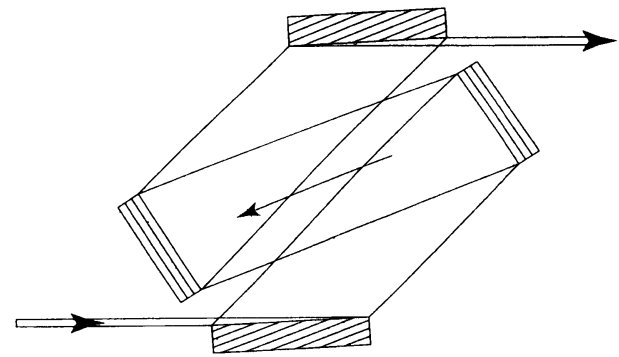

(b)

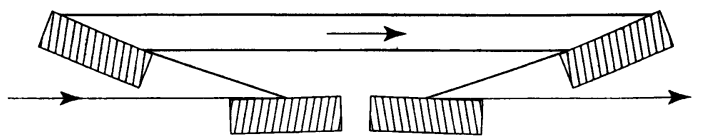

(c)

図4 多重結晶配置の X 線光学系. (X-ray optical system of multi-crystal arrangement.) (a) 平面波化: $(+$, - , + ) 平行配置 (b) 超単色化: $(+,+,-,-)$ 配置 (c) 超単色化: $(+,-,-,+)$ 配置. 


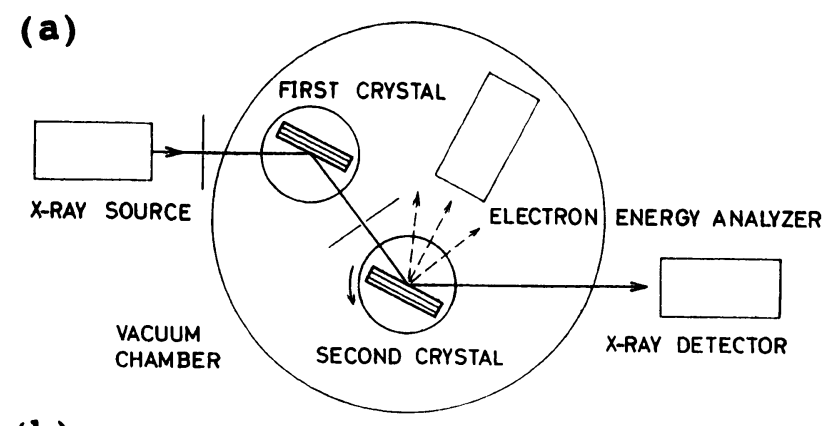

(b)

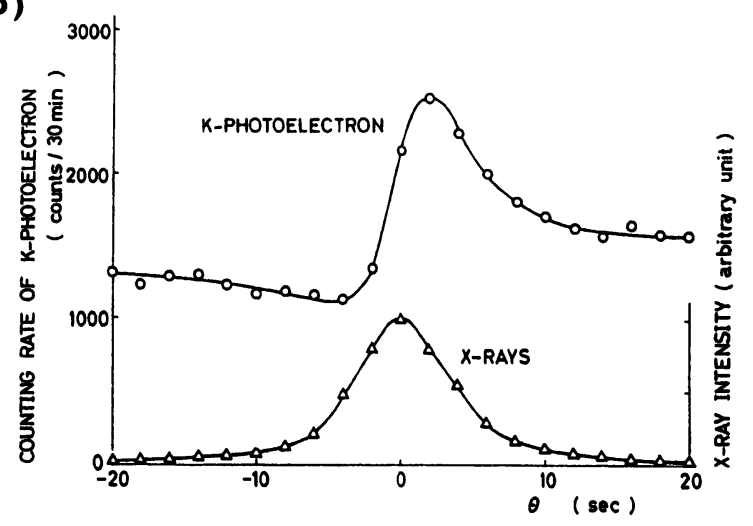

図5 X 線定在波の形成による結晶からの光電子放射の 収量変化. (Anomalous change of electron emission from a single crystal under the $\mathrm{X}$-ray diffraction process.)（a) 真空内 X 線二結晶回折計 (b) $\mathrm{CuK \alpha}$ 線の Si220 面での回折過程で放射される $\mathrm{Si}$ 光電子 の収量変化. 回折強度曲線も図示している.

晶からのペンデル縞を初めて観察し，また極微小な格子 歪みの検出を試みた。

(2) X 線定在波形成による光電子の収量変化の観測

動力学的回折過程で生ずるX線定在波と結晶内原子の 相互作用により光電子やオージェ電子などの二次放射の 収量がブラッグ角近傍で変化するのを初めて観測した （図 5).14) 非対称反射の場合には, 高角入射のほうが低角 入射より収量が際立って大きくなった。これらの観測は 動力学的回折理論とよく一致した. ${ }^{15), 16)}$

(3)中性子線の動力学的回折現象の研究

中性子線でも, 日本原子力研究所の中性子原子炬を用 いて動力学的回折現象の研究を行った. 中性子線では厚 い結晶を用い, 波の扇 (wave fan) あるいはビームの路を 効果的に利用できる. Wave fanの中心部分を取り出して 擬似平面波を得て，それによりブラッグケースのロッキ ングカーブがシルクハット形になるのを初めて観測した. また wave fanの角度拡大作用 ( 105倍)を利用して中性 子線の極微小偏向角を測定した.17) さらにwave fanの中か ら 2 つの路を選び出すタイプの, 2 ブロックからなる干渉 計を考案し, 作製した.18)

\section{$3.2 \times$ 線ビームの高品質化によるX $\mathrm{X}$ 線光学への寄与}

$\mathrm{Si}$ 単結晶はその回折幅が放射光の発散角に近く, 放射

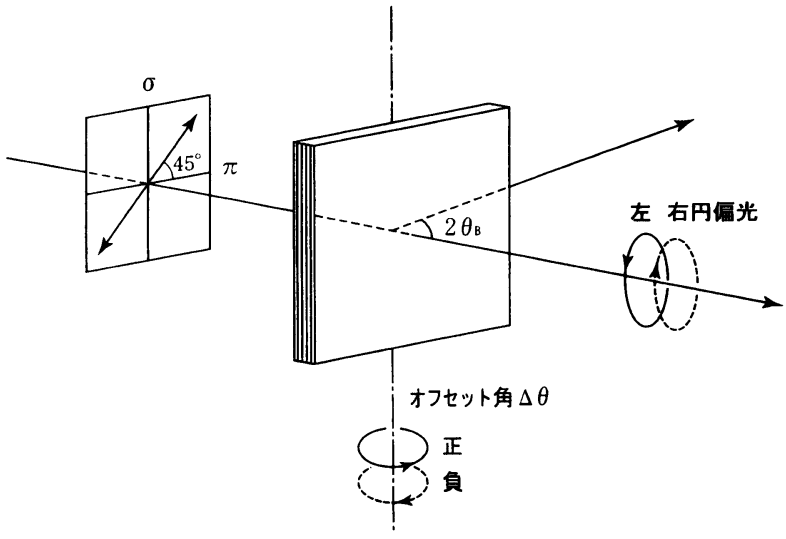

図6 左右円偏光 X 線の作製. (Production of circularly polarized $\mathrm{X}$-rays by $\mathrm{X}$-ray quarter wave plate using Bragg case diffraction.)

光用の $\mathrm{X}$ 線光学素子を作るのに適しており, それにより $\mathrm{X}$ 線光学系が構成される.X線ビームの高品質化のうち, 平面波化についてはすでに述べた。

(1)超単色化

エネルギー幅 $\Delta \mathrm{E}$ を狭くするには，エネルギー分散型の $(+,+)$ 配置が基本で, 高次の非対称反射を組み合わせる とエネルギー幅をより狭くできる. 図 $4 \mathrm{~b} の(+,+,$, , 一) 配置は $(+,+) に(-,-)$ を組み合わせて, 入射方向 と反射方向を一致させてある.これにより $\Delta \mathrm{E} \sim 1 \mathrm{meV}$ のビームが得られる.19)エネルギー幅の下限は実際上 Si 単 結晶の極微小格子歪みによる制約を受けるが, ビーム幅を 狭く限ることで, 図 $4 \mathrm{~b}$ の $(+,-,-,+)$ 配置で $\Delta \mathrm{E} \sim$ $0.1 \mathrm{meV}$ が得られる.20)さらにエネルギー幅を極端に狭く するには, 後述の核共鳴散乱が用いられる. 核共鳴準位の 自然幅に応じて, $\mu \mathrm{eV}$ から neVレベルのエネルギー幅の 超単色ビームが得られる. 最近, 完全性の高い ${ }^{77} \mathrm{FeBO}_{3}$ 結 晶を育成し, ネール温度 $\left(75^{\circ} \mathrm{C}\right)$ 近くまで加熱することに より超微細構造に基づくエネルギー分裂をなくして, 333 反射で $\Delta \mathrm{E}=1.5 \times 10^{-8} \mathrm{eV}$ の超単色の $\mathrm{X}$ 線ビームを得て (る. ${ }^{21}$

(2)円偏光の生成

薄い結晶板を用い,ブラッグケースの回折条件のもとで 透過波に注目すれば, 全反射角度領域の両側のブラッグ角 からずれた角度位置で $\sigma$ 偏光と $\pi$ 偏光の透過波の波数べ クトルに差がある. その移相量が $\pm \pi / 2$ のとき左右円偏光 が得られる. 実際には散乱面から斜め $45^{\circ}$ に傾いた方向の 電場ベクトルをもつ直線偏光の X 線を入射する. このと き $\sigma$ 成分と $\pi$ 成分は可干渉であるので, 円偏光が生成する (図6).さらに結晶を回転してその2つの角度位置の間を 行き来させると, 左右円偏光のスイッチングができる.22,23)

\section{3 結晶表面の構造解析法の開拓}

$\mathrm{X}$ 線表面回折法としては X 線を表面へ微小角で入射さ せて，X線の侵入深さを浅くする手法が先行していた。 こ

日本結晶学会誌 第 48 巻 第 3 号 (2006) 

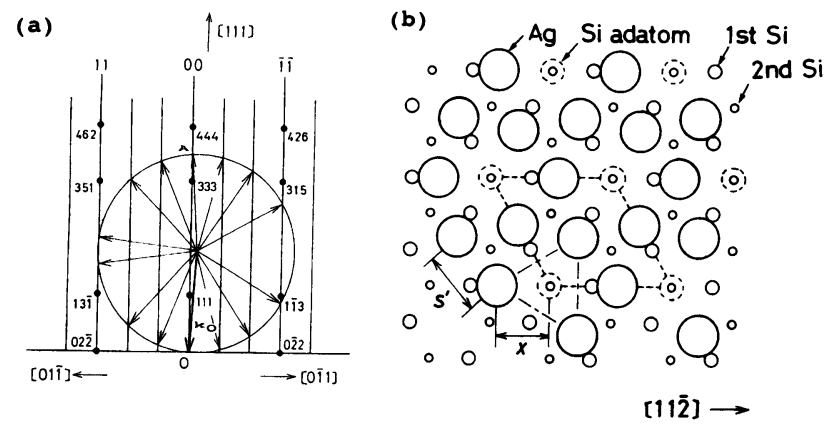

図7 広角入射 ·広角反射の $\mathrm{X}$ 線表面回折法 (a) 波長を 変えながら逆格子ロッドにそって回折強度を測定 (b) 決定された $\mathrm{Si}(111) \sqrt{3} \times \sqrt{3}-\mathrm{Ag}$ 構造. (The $\mathrm{Si}$ (111) $\sqrt{3} \times \sqrt{3}-\mathrm{Ag}$ structure determined by X-ray surface diffraction under the high angle incidence.)

の場合, 散乱ベクトルは表面にほほ平行になり, トランケ ーション・ロッドの根元の部分が測定される.したがっ て結晶構造を表面に平行な面に投影した二次元的な構造 が得られる。これに対して，広角の入射条件で波長を変え ながらトランケーション・ロッドに沿って強度分布を測 定する方法がとられ，表面構造が深さ方向も含めて三次 元的に決められた (図 7)。この場合, 表面層では表面に垂 直な方向に対して周期性をもたないためフーリエ合成は 使えず，いくつかの構造モデルを仮定して回折強度を計 算し, プロファイのフィッティングから構造パラメータ を求める.24) $\mathrm{Si}$ (111) 表面に $\mathrm{Ag}$ を 1 原子層吸着させたと きにできる $\sqrt{3} \times \sqrt{3}$ 構造は, いろいろなモデルが提示され ており，未解決であった. STMによる観察が論争にさらに 火をつけていたが，この方法により図７のように決着し た．表面最上層にある $\mathrm{Ag}$ 原子は三角形状に配列し，その 三角形が蜂の巣状に連結した構造をとる.251.26)

\subsection{X線核共鳴散乱研究の基碟固め}

低い核励起準位をもつメスバウアー同位体にその遷移 エネルギーをもつX線を入射すれば，核準位の自然幅ぐ らいのごく狭いエネルギー範囲で核共鳴散乱を起こす. 核 共鳴散乱振幅の大きさはトムソン散乱と同程度の場合も ある.この核共鳴散乱を利用して，従来のメスバウアー $\gamma$ 線分光の枠を越えた各種の手法が開発された.

(1)核共鳴ブラッグ散乱

核共鳴エネルギーをもつ X 線を共鳴核が三次元的に規 則正しく配列した完全結晶に回折条件を満たして入射す ると，核共鳴ブラッグ散乱が起きる．その場合，動力学的 回折によって結晶中に生ずる波動場が多数の共鳴核と集 団的に相互作用をする結果，個々の励起核の形成は抑制 されて，回折への寄与が大きくなる. ${ }^{57} \mathrm{Fe}$ 同位体で富化し たへマタイト結晶 $\alpha-57 \mathrm{Fe}_{2} \mathrm{O}_{3}$ の（777）面からの核共鳴ブラ ッグ散乱の時間スペクトルを図8に示す.27) 単バンチモー ドでの放射光パルスが入射した後，トムソン散乱は瞬時
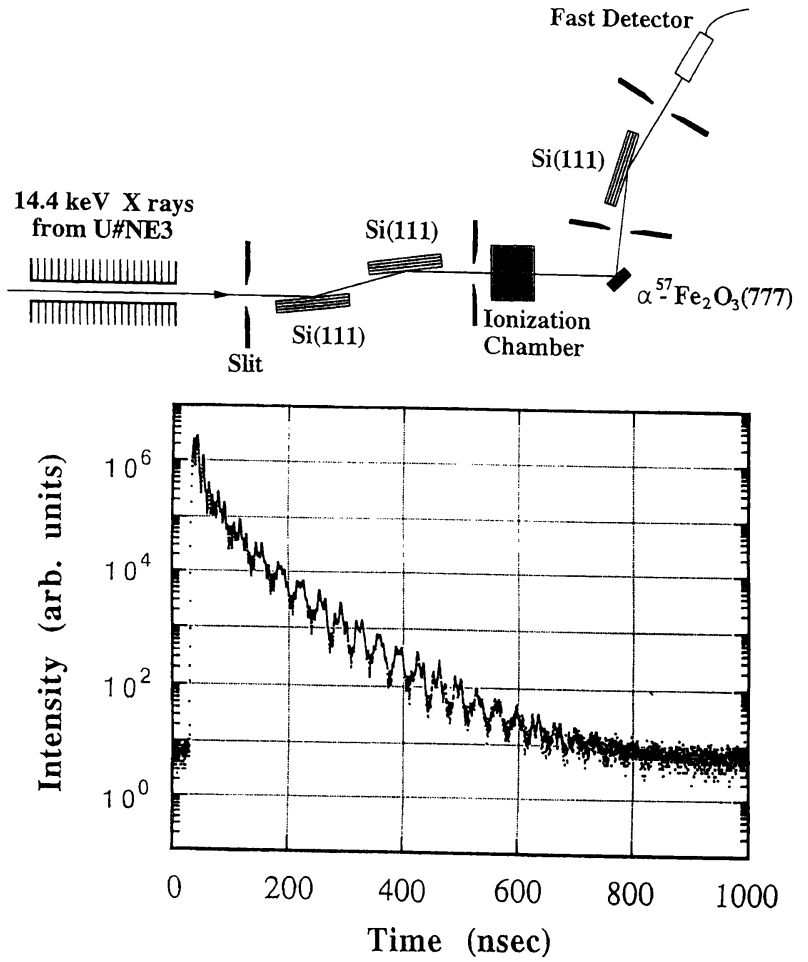

図8へマタイト結晶 $\alpha-{ }^{57} \mathrm{Fe}_{2} \mathrm{O}_{3}$ (777) 面からの核共鳴ブ ラッグ散乱の時間スペクトル. (Time spectrum of nuclear Bragg scattering from ${ }^{57} \mathrm{Fe}_{2} \mathrm{O}_{3}(777)$.) 付図 は実験配置.

に起きるのに対して, 核共鳴散乱はナノ秒オーダーで減衰 しながら続く.孤立した共鳴核では励起準位の自然幅に対 応する約 $100 \mathrm{~ns} の$ 半減寿命で減衰するが，いまの場合， 多数の共鳴核との集団的な相互作用のためにその減衰は スピードアップされる. また, デイケイ・プロファイルに は, 超微細構造をもつ準位からの許容な遷移がすべてコヒ ーレントに励起されるので, それらの間の干渉によって量 子ビートが生ずる、いまの場合は偏光状態と印加磁場の向 きにより超微細構造に基づく6 本の遷移のうち 4 本が許 容になっている.28) - - 方, この核共鳴ブラッグ散乱線が長 い可干渉距離をもつことを利用して, 波面分割型の X 線 干渉計を実現させた.291

(2)核共鳴前方散乱

前方散乱では散乱体の結晶性を問わずに位相が揃うの で, ブラッグ散乱と同じようにディケイ・プロファルに量 子ビートがみられる. 従来のメスバウアー $\gamma$ 線吸収スペク トルがエネルギー軸で測定されるのに対して, 放射光を用 いた核共鳴前方散乱は, 核共鳴ブラッグ散乱の場合と同じ ように時間軸で測定される。 ${ }^{57} \mathrm{FeBO}_{3}$ 結晶に高周波磁場や パルス磁場を印加したときの核共鳴前方散乱の動的過程 が解析された．図9のように高周波磁場が印加すると，磁 気弾性波が生じ結晶中の共鳴核の位置が周期的に変位す る.X線が入射した時刻に共鳴核が同位相で散乱していた ものが, その後位相のずれのために散乱強度が減るが, 初 
めの状態に戻った時刻で強度の増大が観測された。これ は一種のエコータイプの現象である.30)一方, 時間遅れを 伴う核共鳴散乱の干渉現象が, X 線干渉計に共鳴核を含む 位相物体を挿入しドップラー振動させるなどして調べら
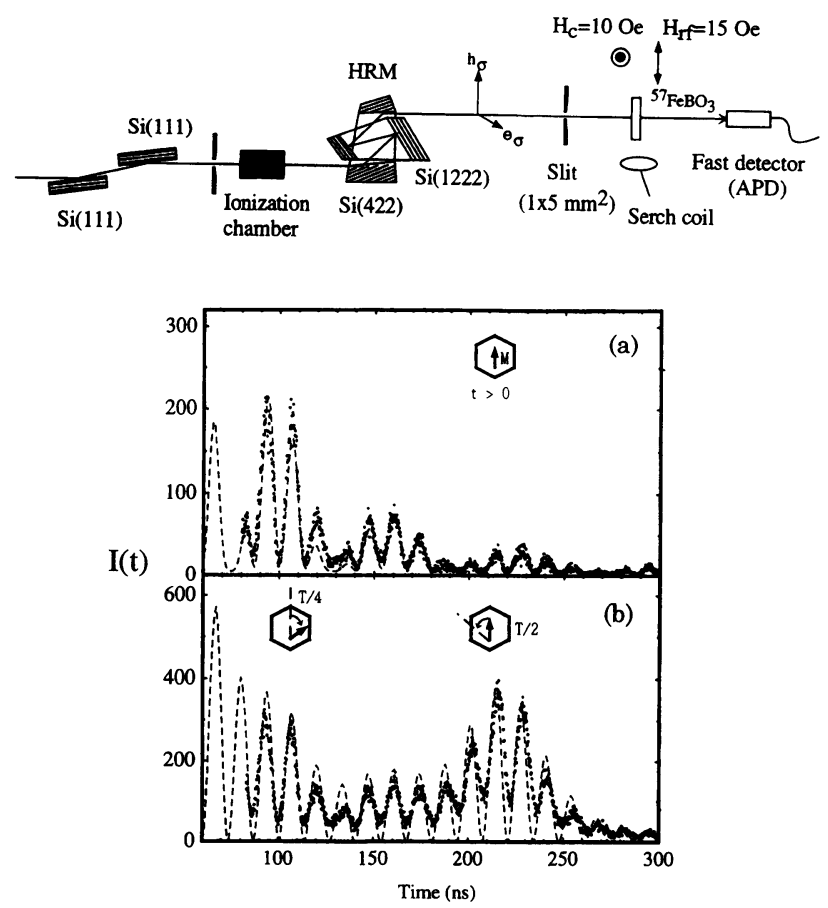

図 9 高周波磁場変調下の ${ }^{57} \mathrm{FeBO}_{3}$ からの核共鳴前方散 乱の時間スペクトル (a) 100e の定常磁場を印加 (b) $15 \mathrm{Oe}, 2.384 \mathrm{MHz}$ の高周波磁場をさらに印加. (Time spectra of nuclear forward scattering from a ${ }^{57} \mathrm{FeBO}_{3}$ thin crystal. (a) Only the static magnetic field is applied and (b) the rf magnetic field is also applied.) 付図は実験配置.
れた.31)

(3)核共鳴非弾性散乱

メスバウアー $\gamma$ 線よりもエネルギー幅の広い放射光を 利用するので, 従来のメスバウアー $\gamma$ 線分光では難しかっ た固体中のフォノンを伴う核共鳴散乱現象が観測された. 入射 $\mathrm{X}$ 線を数 $\mathrm{meV}$ に単色化し, 核共鳴エネルギーを中心 に走査すれば, 散乱体中のフォノンを生成あるいは吸収す るエネルギー分だけ入射エネルギーが増減したところで 核共鳴散乱が生ずる. ${ }^{57} \mathrm{Fe}$ 箔を用いた観測によりフォノン スペクトルの新しい測定法が確立され,32) さらに $\mathrm{Al}, \mathrm{Cu}$ 金 属中における希薄 $\mathrm{Fe}$ 原子の局所的振動状態が解析され た.33) また同様の手法で溶液系への最初の応用が塩酸溶液 中の鉄イオンについて行われた．溶液中での ${ }^{57} \mathrm{Fe}$ の反跳 エネルギーを補った核共鳴励起が観測され，ブラウン運動 によるピークプロファイルの広がりから拡散定数が求め られた、34

\section{$3.5 X$ 線量子光学研究のさきがけ}

\section{(1) 2 光子相関}

可視光やマイクロ波で観測された 2 光子がかかわる強 度の干渉であるハンブリーブラウンーツイスの実験を MR からの放射光を用いて X 線領域で試みた (図10). 放射光 は $\mathrm{Si}$ 高分解能モノクロメーターによって $\Delta \mathrm{E}=6 \mathrm{meV} に$ 時間的コヒーレンスを高くしたうえで, スリット幅を $20 \mu \mathrm{m}$ まで狭くして空間的コヒーレンスの高い状態でビームス プリッターのSi 結晶に入射した，透過方向と回折方向に 進む 2 光子のコインシデンスのレートを測定すると, 光子 のバンチング効果によってランダムコインシデンスに比 べて $0.6 \%$ 増加しているのが初めて観測された.35),36) これ は光源の特性評価にも役立つ.

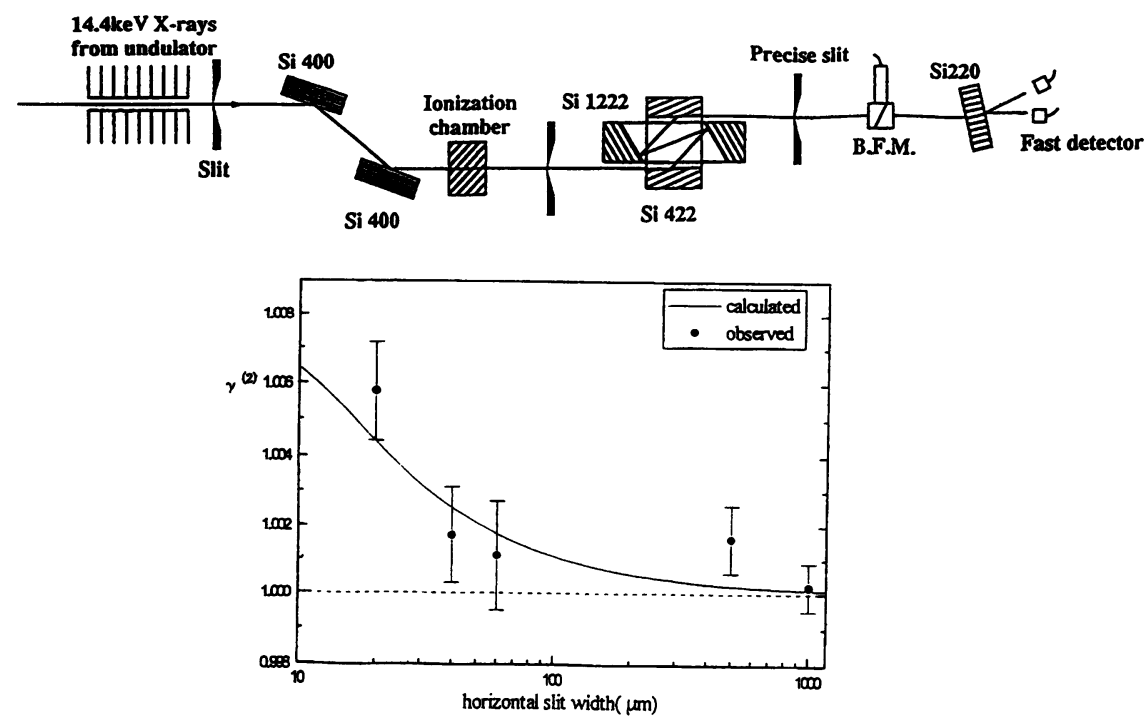

図 $10 \mathrm{SRX}$ 線の 2 光子相関, 二次のコヒーレンス関数 $\gamma^{(2)}$ のスリット幅による変化を測定. (Two-photon correlation of X-rays from synchrotron radiation source analogous to Hanbury-Brown and Twiss experiment.) 付図は実 験配置. 

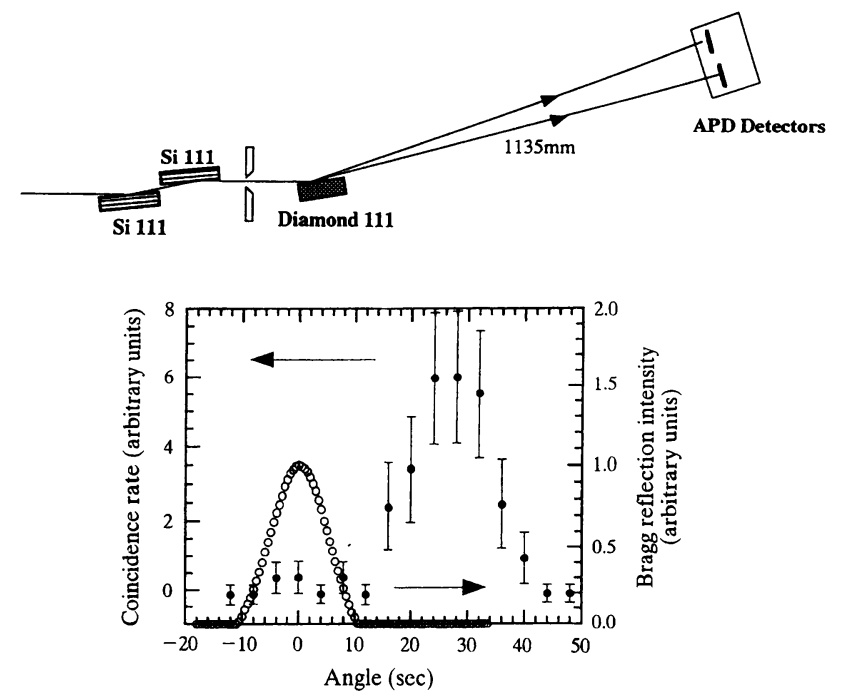

図 $11 \mathrm{X}$ 線パラメトリック変換 $(0.65 \AA \AA$ の X 線, ダイヤ モンド結晶, 400 反射) 結晶の回転角の関数として 測定されたパラメトリック变換のコインシデンス レートと回折強度. (Spontaneous X-ray parametric conversion in a diamond crystal.) 付図は実験配置.

\section{(2) 2 光子生成}

光学のパラメトリック变換では, 1 つの光子が非線形感 受率をもつ媒質に入射し吸収されて, エネルギー保存則

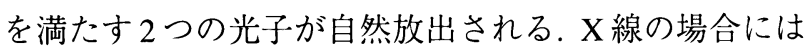
それと異なって, 逆格子ベクトルを含めた形で位相整合条 件を满たさせる.ダイヤモンド結晶でブラッグ角から高角 側へわずかに回転させて, 2 方向へ放射される 2 光子がコ インシデンス法により検出された(図 11)．37)これはX線 非線形光学研究への端緒の 1 つである.

\section{4. 放射光科学の発展と将来}

PF の供用開始からすでに 24 年も経過し, SPring-8の供 用開始からでも 8 年を越えており，その間わが国のSRX 線を利用する研究は質・量ともに飛躍的に発展している. 生命科学, 物質科学, 地球科学, 環境科学などの基礎科学 から, バイオテクノロジー, ナノテクノロジーなどの応用 研究まで広範な科学・技術の分野でめざましい貢献をし てきた. 産業界からの利用が着実に拡大しているのも，ま ことに喜ばしい．初期には放射光技術の専門家やそれに 近い研究者の利用が多かったが, 施設側の努力により，そ れにまったく慣れていない諸分野の専門家が利用するよ うになっている. ラボ X 線と同じように放射光のッール 化が進んでいると言える.

解析手法や技術面での進歩で注目すべき点を挙げると， (1) まず結晶構造解析では三次元の周期性をもつ結晶の 解析から二次元の周期性をもつ結晶表面 ·界面の解析が できるようになり，最近では量子細線のような一次元周 期のものも解析の対象になっている. さらに孤立した $(0$
次元の) 分子の解析も視野に入ってきた. (2) 構造解析は もともと原子配置を決めるのが主目的で, その高精度化が 図られてきた. その一方で, 結晶内の電子密度分布がリ一 トベルト法/最大エントロピー法により正確に得られる ようになり，またATS 散乱により軌道秩序が観測される ようになり，物性の解析に役立っているのは特筆すべきこ とである. (3) タンパク質の結晶構造解析の最近の進展は 私の予想を超えている. ハイスループットの測定システム による解析が大量に行われるとともに, 難解な巨大分子複 合体の解析も進められている. (4) 物質の構造評価のため のイメージングでは, 回折, 屈折, 吸収や位相コントラス トによるイメージング, X線マイクロトモグラフィ, 結像 型と走査型の $\mathrm{X}$ 線顕微鏡, コヒーレント $\mathrm{X}$ 線散乱顕微法 などの多種多様な手法が展開されている.（5）別の観点か らみれば，放射光とコンピュータの組み合わせが威力を 発揮している. 放射光を用いて取得される高精度のデー タがコンピュータによるパラメータ・フィッティングな どに活かされて, 例えばリートベルト法, 最大エントロピ 一法, 逆モンテカルロ法, オーバーサンプリング法の解析 で従来不可能であったような新しい解析結果が得られて いる. (6) 放射光の効果的な利用には, 高性能の検出器の 開発の果たしている役割も大きい. 特に二次元検出器のイ メージングプレートや CCD の出現はインパクトを与えて おり,ラボX線の守備範囲も広げている.

放射光 X 線源についてみれば, 今後りニアック形加速 器の発展が期待されている.X線自由電子レーザーでは, 長尺のアンジュレーターの入り口付近で放射された光が種 として働き, 電子集団が次第にマイクロバンチ化し, 増幅 した自然放射が生ずる. 理化学研究所がSPring-8のサイト にSPring-8 Compact SASE Source (SCSS) の建設をするこ ととなった.これは米国とドイツの計画 (LCLS と EXFEL) の半分程度のスケールのコンパクトタイプで同じような 性能をもつ. それから得られる放射光には従来の放射光に ない高ピーク輝度, 極短パルス, 高コヒーレンス (高光子 縮重度)の特長がある.これにより反応過程, 非平衡系・ 過渡現象などを追跡する極短時間分解実験や, 単分子観察 をめざすコヒーレント X 線散乱顕微鏡, X 線量子光学な どのコヒーレンスのかかわる実験が発展し,さらに強光子 場科学など未踏の研究分野が開拓されると期待されてい る.これまでのリング形加速器の放射光光源は高平均輝度 の特長によりいわば百貨店的に広範な研究課題に利用さ れるのに対して,この光源は専門店的に特化した研究課題 に利用されることになり，両者は相補的な役割をもつ。一 方，すでに 24 年ぐらい共用されているPFリングについて は後継加速器としてエネルギー回収型リニアックの建設 が計画されている. この方式では, 電子ビームがRFエネ ルギーにより加速されるとともに, RFが逆位相のときに 減速して RFエネルギーとして回収し，それが周回部を通 
って戻ってくる電子の加速に利用される，これから得ら れる放射光は高平均輝度, 極短パルスの特長をもち, コヒ ーレンスもかなり高い. したがって百貨店的な利用とと もに極短時間分解実験などが可能で専門店的な利用もで きる。

放射光科学は上述のようにまさに成熟期に入っており, 今後既存の放射光施設を利用して多くの研究分野の発展 に一層貢献するであろう。さらにX線自由電子レーザー などの実現によって未踏の研究領域が開拓されるのが期 待される。

\section{謝 辞}

最後になりますが，40数年にわたる長い研究生活でお 世話になった多くの方々に心から感謝いたします。特に 高良和武先生にはX 線動力学的回折とそれによるX 線光 学のご教示をいただき,ささらに放射光科学の推進につい てご指導をいただきました，过 泰先生には超高真空内で のX線回折実験をするきっかけを与えていただきました， 各種の研究課題は, 東大・教養では中野 滋, 高野幸男, 安 中正一, 杉田吉充, 生産研では寺田啓子, 青木貞雄, 工学 部では高橋敏男, 石川哲也, 泉弘一, 平野馨一, 依田芳卓 などの諸氏との共同で行われたものです，当時院生の鈴 木カルロス健一, 秋本晃一, 中谷信一郎, 後藤俊治, 張 小 威, 百生 敦, 長谷川祐司, 工藤喜弘, 斎藤 彰, 三井隆也, 小山一郎, 矢橋牧名, 今井康彦などの諸氏は独自の研究を 展開しました。星埜禎男先生をはじめ, 武居文彦, 藤井保 彦, 雨宮慶幸, 瀬戸 誠の諸氏にも研究面でお世話になり ました. 放射光利用の推進に関しては, KEK では佐々木泰 三, 千川純一, 安藤正海, 松下 正, SPring-8関係では上坪 宏道, 塩谷亘弘, 植木龍夫, 下村 理をはじめ多くの先輩, 同僚の諸氏とのお付き合いは, かけがえのないものでし た。これらの皆様の捻で放射光とのめぐりあわせを有 意義に展開させることができました。

\section{文 献}

1) 菊田惺志：日本結晶学会誌 18, 65 (1976).

2) 1971 年度科研費 (総合研究 B)「超高出力の $X$ 線発生装置に関す 万研究」報告書.

3) 安藤止海, 菊田惺志: 日本物理学会誌 50, 15 (1995).

4）日本放射光学会将来計画特別委員会：次世代大型放射光計画に 関する調查報告書, 放射光 3, 205 (1990).

5）日本放射光学会将来計画特別委員会：中型放射光施設計画に関 する調查報告書, 放射光 4, 199 (1991).

6) 財団法人高輝度光科学研究センター 10 年史 高輝度光科学研究 センター編集・発行, 2001.

7) 上坪宏道, 㐘田惺志: 日本物理学会誌 44, 787 (1989).

8）菊田惺志：放射光 9, 379 (1996).

9）菊田惺志：日本結晶学会誌 21, 327 (1979).

10) S. Kikuta and K. Kohra: Phys. Soc. Japan 29, 1322 (1970).

11) S. Kikuta: Phys. Soc. Japan 30, 222 (1971).
12) S. Kikuta: Phys. Stat. Sol. (b) 45, 333 (1971).

13) S. Kikuta and K. Kohra: J. Phys. Soc. Japan 25, 924 (1968).

14) S. Kikuta, T. Takahashi and Y. Tuji: Phys. Letter 50A, 453 (1975).

15）高橋敏男, 菊田惺志：応用物理 47, 853 (1978).

16) T. Takahashi and S. Kikuta: J. Phys. Soc. Japan 46, 1608 (1979).

17) S. Kikuta, T. Ishikawa, K. Kohra and S. Hoshino: J. Phys. Soc. Japan 39, 471 (1975).

18) S. Kikuta, T. Takahashi, K. Nakayama, Y. Fujii and S. Hoshino: J. Phys. Soc. Japan 45, 715 (1978).

19) T. Ishikawa, Y. Yoda, K. Izumi, C. K. Suzuki, X. W. Zhang, M. Ando and S. Kikuta: Rev. Sci. Instrum. 63, 1015 (1992).

20) M. Yabashi, K. Tamsaku, S. Kikuta and T. Ishikawa: Rev. Sci. Instrum. 72, 4080 (2001).

21）三井隆也, 武居文彦, 北尾真司, 増田 亮, 瀬戸 誠, 依田芳卓, 張 小威, 㐘田惺志: 日本物理学会講演, 2005 年 9 月, 同志社大.

22）平野馨一, 石川哲也, 菊田惺志: 放射光 4, 357 (1991).

23) K. Hirano, T. Ishikawa and S. Kikuta: Rev. Sci. Instrum. 66, 1604 (1995).

24）高橋敏男, 菊田惺志: 応用物理 55, 978 (1986).

25) T. Takahashi, S. Nakatani, T. Ishikawa and S. Kikuta: Surf. Sci. 191, L825 (1987).

26) T. Takahashi, S. Nakatani, N. Okamoto, T. Ishikawa and S. Kikuta: Jpn. J. Appl. Phys. 27, L753 (1988).

27) S. Kikuta: in Resonant Anomalous X-ray Scattering (ed. G. Materlik et al.) Elsevier Science, p.635, 1994.

28）菊田惺志：日本物理学会誌 50, 630 (1995).

29) K. Izumi, T. Mitsui, M. Seto, Y. Yoda, T. Ishikawa, X. W. Zhang, M. Ando and S. Kikuta: Jpn. J. Appl. Phys. 34, 5862 (1995).

30) T. Mitsui, T. Shimizu, Y. Imai, Y. Yoda, X. W. Zhang, H. Takei, T. Harami and S. Kikuta: Jpn. J. Appl. Phys. 36, 6525 (1997).

31) Y. Hasegawa and S. Kikuta: Hyperfine Interactions 123/124, 721 (1999).

32) M. Seto, Y. Yoda, S. Kikuta, X. W. Zhang and M. Ando: Phys. Rev. Lett. 74, 3828 (1995).

33) M. Seto, Y. Kobayashi, S. Kitao, R. Haruki, T. Mitsui, Y. Yoda, S. Nasu and S. Kikuta: Phys. Rev. B61, 11420 (2000).

34) X. W. Zhang, Y. Yoda, M. Seto, Yu. Maeda, M. Ando and S. Kikuta: Jpn. J. Appl. Phys. 34, L330 (1995).

35) Y. Kunimune, Y. Yoda, K. Izumi, M. Yabashi, X. W. Zhang, T. Harami, M. Ando and S. Kikuta: J. Synchrotron Rad. 4, 199 (1997).

36）㐘田惺志, 国宗依信, 依田芳卓, 泉 弘一, 小山一郎, 矢橋牧名, 張 小威, 安藤正海, 原見太幹: 放射光 10, 218 (1997).

37) Y. Yoda, T. Suzuki, X. W. Zhang, K. Hirano and S. Kikuta: $J$. Synchrotron Rad. 5, 980 (1998).

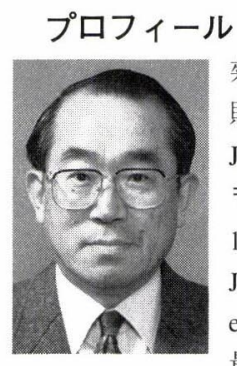

菊田惺志 Seishi KIKUTA

財団法人高輝度光科学研究センター

Japan Synchrotron Radiation Research Institute

$\overline{\mathrm{T}}$ 679-5198 兵庫県佐用郡佐用町光都 1-1-1

1-1-1 Kouto, Sayo-cho, Sayo-gun, Hyogo 679-5198,

Japan

e-mail: kikuta@spring8.or.jp

最終学歴: 東京大学理学部物理学科

専門分野：X線物理

趣味：草木の育成と観賞 